AARP INTERNATIONAL THE JOURNAL

VOLUME $11-2018$ EDITION

Real Possibilities

\title{
Livable Communities for All
}

By Nancy LeaMond 


\title{
Livable Communities for All
}

\author{
By Nancy LeaMond
}

In 201 $\mathrm{n}$ his address at Harvard University's 2017 commencement ceremony, Facebook CEO Mark Zuckerberg said, "Change starts local. Even global changes start small - with people like us." This concept neatly encapsulates the work that AARP is doing to make the places where we live great for people of all ages. Local communities are on the front lines addressing the needs of an aging population. Today, there are approximately 46 million people in the United States over age 65 , and that number will grow over the next 15 years to 73 million. That's one out of every five people nationwide. People are living longer and managing chronic conditions over an extended period of time. And, more and more, people want to stay in their communities as they age.

Rising to the challenge of this "demography-is-destiny" future requires change.

The good news is that the things making it easier for older adults to stay in their homes and communities also support the population at large. As it turns out, whatever our age, we ALL want the same things: safe, affordable housing and transportation options; good health for ourselves, our loved ones and our environment; opportunities to learn, support our families and enjoy our lives; a connection with our neighbors and a government that is responsive to our needs.

For nearly a decade, AARP has promoted local change to build communities where people of all ages can thrive. We work in partnership with residents, community leaders and public officials of all stripes in close to 300 towns and cities across the United States. Much of this work is done through the AARP Network of Age-Friendly Communities, which today comprises 200 communities representing nearly 67 million people.

Another valuable role that AARP plays is to shine a spotlight on local efforts, dig deeper into how ideas are being turned into action and make it a little easier for community leaders to learn from one another. One of my favorite sayings among America's mayors is that they "love being the first to be second." They learn from their peers and copy what works.

That's the premise behind our Where We Live books, which are free compilations that serve as a reference point for what others are doing so good ideas can be copied or adapted to other communities.

The first edition of Where We Live focused on policies and projects promoted by mayors. More than any other type of elected official I can think of, mayors get things done. But they aren't the only ones working hard to improve communities. City and town council members, county commissioners, leaders of nonprofit and social service organizations, business executives and just regular folks are all doing their part. So, the latest edition of Where We Live takes a broader look at what's happening on the ground, recognizing that good ideas and the energy to push them forward can come from any number of sources.

And, in 2017, AARP launched a Community Challenge Grant program to help communities take quick action on short-term projects. Sometimes the first step toward making a difference in a community can be the most difficult. Having success with something modest can build momentum for bigger things to come. In total, AARP is providing $\$ 785,000$ to the winning 91 projects. The average grant is around $\$ 8,500$, and 


\section{"Our new Roadmap to Livability is a 'do it yourself' guide to help residents get started on the path to improving their communities."}

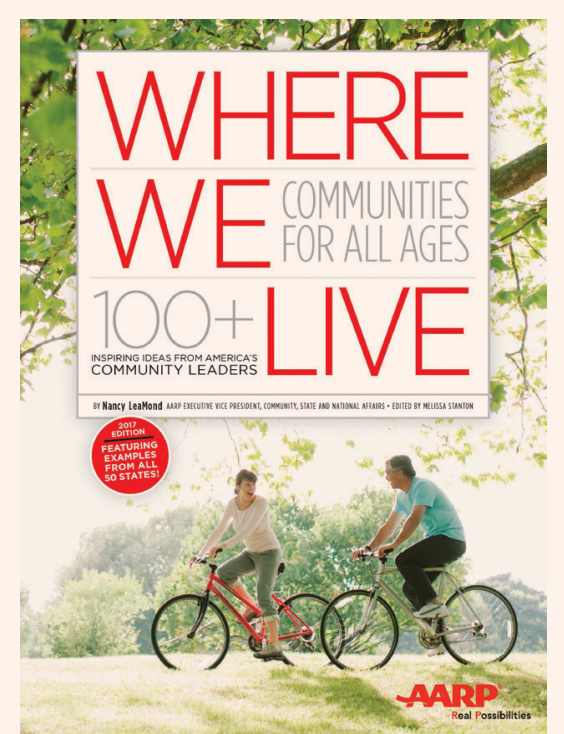

there are a lot of really interesting projects that requested less than $\mathrm{H} 5,000$.

Moving forward, AARP is committed to helping community leaders drive even more local change. We're gearing up for another round of Community Challenge grants in 2018 and will be deploying teams of AARP staff and experts to help communities overcome obstacles and implement creative solutions.

We're also creating tools to help individual citizens take action in their communities. Our new Roadmap to Livability is a "do it yourself" guide to help residents get started on the path to improving their communities.

Most important, AARP is listening - to our members, volunteers, and
AARP's Where We Live features inspiring ideas from some of America's community leaders

local leaders in communities across the United States. We want to hear from the folks on the ground to learn how AARP can support their efforts and be responsive to their needs as we work in partnership to make a difference in communities across America.

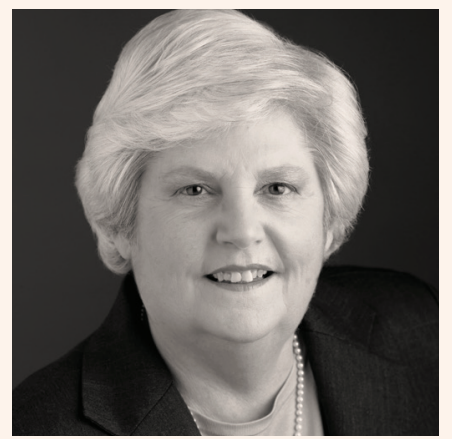

Nancy LeaMond EXECUTIVE VICE PRESIDENT AND CHIEF ADVOCACY \& ENGAGEMENT OFFICER, AARP 
AARP International engages global stakeholders to spark solutions that strengthen communities, protect the vulnerable and enable people around the world to pursue their goals and dreams. Working with governments, civil society and the private sector, we are focused on enhancing the quality of life for people as they age. We serve as the global voice for AARP, a social change organization with a membership of more than 37 million.

THE JOURNAL ONLINE

aarpinternational.org/journal

AARP INTERNATIONAL ONLINE

aarpinternational.org

FACEBOOK

facebook.com/aarpintl

TWITTER

@aarpintl

CONTACT

AARP International

601 E Street, NW

Washington, DC 20049

United States

T +1 2024342398

E international@aarp.org

AARP International: The Journal is a publication of AARP. The views expressed herein do not necessarily represent policies of AARP and should not be construed as endorsements. The mention of a product or service herein is solely for information to our readers and may not be used for any commercial purpose. AARP, which was established in 1958, is a nonprofit, nonpartisan organization with tens of millions of members ages 50 and older. State offices are located in all 50 states, the District of Columbia, Puerto Rico, and the Virgin Islands.

January 2018

()2018, AARP

Reprinting with permission only. 